\title{
SKUTECZNOŚĆ KOMUNIKATÓW PERSWAZYJNYCH ODWOEUJĄCYCH SIĘ DO BYCIA „DOBRĄ MATKĄ", SKIEROWANYCH DO MATEK DZIECI W WIEKU PRZEDSZKOLNYM
}

\author{
Justyna Chochorowska \\ Instytut Psychologii Uniwersytetu Wrocławskiego \\ ul. Dawida 1, 50-527 Wrocław, Polska \\ E-mail: chochorowska6@interia.pl \\ ORCID: https://orcid.org/0000-0003-2241-6878 \\ Maria Pius \\ Instytut Psychologii Uniwersytetu Wrocławskiego \\ ul. Dawida 1, 50-527 Wrocław, Polska \\ E-mail: marypiu97@gmail.com \\ ORCID: https://orcid.org/0000-0001-6663-2789 \\ Weronika Sielicka \\ Instytut Psychologii Uniwersytetu Wrocławskiego \\ ul. Dawida 1, 50-527 Wrocław, Polska \\ E-mail:wmsiel@gmail.com \\ ORCID: https://orcid.org/0000-0002-8355-6615 \\ Natalia Szymańska \\ Instytut Psychologii Uniwersytetu Wrocławskiego \\ ul. Dawida 1, 50-527 Wrocław, Polska \\ E-mail: nat.szy1@wp.pl \\ ORCID: https://orcid.org/0000-0001-6730-1527
}

\section{Abstrakt}

Cel badań. Celem badań było empiryczne sprawdzenie hipotezy, że skierowany do matek komunikat perswazyjny, który wywołuje presję bycia dobrą matka, jest bardziej skuteczny niż taki komunikat, który nie wywołuje presji bycia dobrą matką.

Metody badań. W badaniu wzięły udział $N=64$ matki dzieci przedszkolnych, w wieku od 21 do 47 lat, posiadających od 1 do 4 dzieci, w wieku od 5 miesięcy do 20 lat. Badanie przeprowadzono w modelu eksperymentalnym. Dane zebrano za pomocą ankiety ewaluacyjnej dotyczącej materiału bodźcowego oraz wywiadu z osobami badanymi na temat treści komunikatów perswazyjnych.

Wyniki badań. Uzyskane dane wykazały, że materiał bodźcowy, który zawierał komunikat odwołujący się do bycia dobrą matką, okazał się średnio bardziej skutecz- 
ny, niż nieodwołujący się do bycia dobrą matką. Wyniki analizy testem U Manna-Whitney'a wykazały jednak, że różnice między grupami nie są istotne statystycznie, w związku z czym podjęto się analizy jakościowej wypowiedzi osób badanych na temat treści komunikatów. Analiza statystyczna danych jakościowych przy użyciu testu chi-kwadrat nie wykazała istotności statystycznej.

Wnioski. Wyniki nie potwierdzają przyjętej hipotezy. Komunikat perswazyjny odwołujący się do bycia dobrą matką nie był bardziej skuteczny, niż komunikat nieodwołujący się do bycia dobrą matką. Możliwymi wyjaśnieniami uzyskanego efektu są model dwutorowości perswazji (Petty, Cacioppo, 1990) oraz wpływ emocji na skuteczność komunikatu perswazyjnego (Leventhal, 1970). Chociaż wyniki uzyskane w eksperymencie nie potwierdziły przyjętej hipotezy, mimo wszystko sugeruja, że warto kontynuować badania w tym zakresie, nie posługując się jedynie kwestionariuszem i wywiadem ustrukturyzowanym, ale mierząc rzeczywiste zachowania osób badanych.

Słowa kluczowe: dobra matka, matka idealna, presja macierzyństwa, matczyna wina, poczucie winy u matek, skuteczność perswazji, wina a perswazja

The effectiveness of persuasive messages referring to being a ,good mother", addressed to mothers of preschool children

\section{Abstract}

Aim. The aim of the research was to test empirically the hypothesis that a persuasive message which creates pressure to be a good mother, addressed to mothers, is more effective than a message that does not create the pressure to be a good mother.

Research methods. The study involved 64 mothers of pre-school children, aged 21 to 47 , with between 1 and 4 children, aged from 5 months to 20 years. The study was carried out in the experimental model. Data was collected using an evaluation questionnaire concerning the stimulus material and an interview with the subjects on the content of the persuasive messages used.

Results. The data obtained showed that the stimulus material which contained the message referring to being a good mother turned out to be on average more effective than the material not referencing being a good mother. However, the results of the Mann-Whitney $U$ test showed that the differences between the groups are not statistically significant. Therefore, a qualitative analysis of respondents' opinions on the content of the messages was made. A statistical analysis of qualitative data using the chi-square test did not show statistical significance.

Conclusions. The results do not confirm the adopted hypothesis. A persuasive message, referring to being a good mother, was not found to be more effective than a message that did not refer to being a good mother. Possible explanations for the effect obtained are the model of persuasion dualism (Petty, Cacioppo, 1990) and the influence of emotions on the effectiveness of the persuasive message (Leventhal, 1970). Although the results obtained in the experiment did not confirm the accepted hypothesis, they nevertheless suggest that it is worth continuing research in this field, not only using a questionnaire and structured intelligence, but also measuring the real behaviour of the subjects.

Key words: good mother, perfect mother, maternal pressure, mother's fault, maternal guilt, effectiveness of persuasion, guilt and persuasion 


\section{INSPIRACJA DO BADANIA}

Inspiracją do przeprowadzenia badania dotyczącego skuteczności komunikatów perswazyjnych odwołujących się do bycia „,dobrą matką" była lektura artykułu Motherhood Is Hard to Get Wrong. So Why Do So Many Moms Feel So Bad About Themselves? (Trudno jest źle wypetnić rolę macierzyńską. Dlaczego więc tak wiele matek myśli źle o sobie?) (Howorth, 2017) w czasopiśmie „Time”, amerykańskim tygodniku społeczno-politycznym. „Time” ma największy nakład spośród amerykańskich czasopism, a poruszenie w nim takiego tematu wskazuje na konieczność debaty społecznej na temat presji odczuwanej przez matki. Postanowiono zgłębić wiedzę na temat presji bycia dobrą matką oraz „mitów” wokół macierzyństwa. Mimo że jeszcze w ubiegłym wieku, wybitny brytyjski pediatra i psychoanalityk Donald Winnicott (1965) ukuł termin „wystarczająco dobra matka”, podkreślający, że matka nie musi być „idealnym rodzicem” (gdyż idealni rodzice nie istnieją), lecz jedynie w sposób wystarczająco dobry spełniać swą matczyną funkcję, presja i poczucie winy wydają się wciąż obecne. Zebrane materiały źródłowe ukazują obraz matki jako kobiety udręczonej przez poczucie winy i wstyd. Istnieją natomiast nieścisłości w definicji przyczyn tego zjawiska. Wiele źródeł za przyczynę podaje potrzebę (według niektórych źródeł wywoływaną przez standardy społeczne) matek do dążenia do bycia matką idealną lub „dobrą matką”. Brak z kolei jasnej definicji „,matki idealnej” lub „dobrej matki” - rozumienie tych terminów przez kobiety jest bardzo zróżnicowane. Niektóre źródła twierdzą z kolei, że poczucie winy i wstyd są wręcz wpisane w rolę matki.

Kolejnym źródłem inspiracji były artykuły popularnonaukowe na temat wprowadzonych przez portale internetowe polityk dopasowywania treści reklam pod użytkowników portalu. Prowadzi to do wystawienia użytkowników na działanie reklam dobranych na podstawie ich aktywności w Internecie (Sample, 2017). Skutkiem tego jest zarzucanie kobiet reklamami podobnymi treściowo do ich zainteresowań i potrzeb. Konieczne są dlatego rozważania na temat etyki takich zabiegów marketingowych, a przede wszystkim postawienie pytania, czy presja bycia dobrą matką może zostać wykorzystana do tego rodzaju marketingu. Innymi słowy, czy materiały reklamowe (a więc komunikaty perswazyjne), które mają na celu wywołanie w matkach presji bycia „,dobrą matką”, są skuteczne. Postanowiono zatem zbadać, czy we współczesnym polskim społeczeństwie (w którym wciąż określenie „matka Polka” jest głęboko zakorzenione), komunikaty skierowane do matek, które wywołują presję bycia dobrą matka, są skuteczniejsze niż takie komunikaty skierowane do matek, które tej presji nie wywołują.

\section{WSTĘP TEORETYCZNY}

W kulturze XXI wieku pojęcie „matczynej winy” jest tak wszechobecne, że można odnieść wrażenie, że poczucie winy jest nieodłączną częścią macierzyństwa (Sutherland, 2010). Cytowana autorka wskazuje, że inwestygacja przyczyn poczucia winy u matek powinna być osadzona w kontekście etnicznym i ekonomicznym. Natomiast elementem wspólnym dla matek ze wszelkich środowisk jest występowanie idei „dobrej matki" - innymi słowy, wymagań dotyczących tego, jaka powinna być matka. Owe wymagania różnią się pomiędzy grupami matek (dzielonymi ze względu na 
pochodzenie, status materialny, wykształcenie, etc.). Natomiast wszystkie matki odczuwają presję spełnienia tych wymagań, czyli bycia „,dobrą matką".

Obecnie wymagania bycia „dobrą matką" przyjmują formę różnorakich ideologii na temat macierzyństwa (Johnston, Swanson, 2006). Ideologia, która wydaje się być obecnie najbardziej popularna, jest ",intensive mothering" - intensywne matkowanie (Johnston, Swanson, 2006), po raz pierwszy opisane przez S. Hays w 1996 roku. Badacze nadali temu zjawisku różne nazwy: „matka idealna” Peggy Orenstein (2001), „nowy mamizm” Susan Douglas i Meredith Michaels (2004) i „,mommy mystique” Judith Warner (2005). Te terminy opisują model macierzyństwa, które pochłania kobiety fizycznie, emocjonalnie, psychicznie i intelektualnie (Sutherland, 2006). Ten trend doprowadza do wytworzenia i propagowania „mitu dobrej matki” - spełniającej standardy, które są wręcz niemożliwe do spełnienia. Taka matka potrafi znaleźć równowagę w życiu, wewnętrzny balans, szczęście i spełnienie podczas swoistej żonglerki obowiązkami: prowadzenie kariery na jednym froncie oraz utrzymywanie idealnego domostwa i całkowite poświęcanie się wychowywaniu potomstwa na drugim. Matki muszą wychować dzieci zdrowe, dobrze przystosowane, pewne siebie i osiagające sukcesy. Próby sprostania tym wymaganiom budzą w matkach złość, frustrację i poczucie winy (Sutherland, 2006).

Mit „dobrej matki” jest podtrzymywany przez media, które bombardują kobiety obrazami idealnego macierzyństwa, czy to w filmach, serialach, czy reklamach. Na okładkach czasopism matki prezentowane są jako seksowne, zadbane i permanentnie uśmiechnięte. Narracja uwidaczniająca trudy macierzyństwa w opozycji do wyidealizowanego przekazu jest marginalna. Powoduje to, że presja bycia „dobrą matką" jest wszechobecna (Sutherland, 2006).

Jednocześnie badania dostarczają dowodów na to, że poczucie winy u adresata perswazji wzmaga skuteczność tej perswazji: Sally Hibbert, Andrew Smith, Andrea Davies i Fiona Ireland (2007) w badaniach nad charytatywnością dowiedli, że występuje pozytywna korelacja pomiędzy skłonnością do zachowań charytatywnych a poczuciem winy. Im wyższy był poziom winy osoby badanej w odpowiedzi na komunikat perswazyjny, tym bardziej była ona skłonna do wpłacenia datku na fundację charytatywną.

Wpływ poczucia winy na uległość był już wcześniej szeroko opisywany. Już w 1969 roku J. Merrill Carlsmith i Alan Gross dowiedli eksperymentalnie, że poczucie winy wzmacnia uległość. Co więcej, poczucie winy jest bardziej skuteczne we wzmaganiu uległości niż poczucie sympatii (Carlsmith, Gross, 1969).

Na podstawie przeglądu literatury przyjęto zatem hipotezę: skierowany do matek komunikat perswazyjny, który wywołuje presję bycia dobrą matką jest bardziej skuteczny niż taki komunikat, który nie wywołuje presji bycia dobrą matką.

\section{Metodologia \\ Osoby badane}

W badaniu sędziów kompetentnych wzięło udział 30 matek dzieci przedszkolnych, w wieku od 29 do 42 lat $(M=34,8 ; S D=4,8)$, posiadających od 1 do 3 dzieci $(M=$ $1,7 ; S D=0,65)$, w wieku od 1 do 12 lat $(M=4,6 ; S D=2,48)$.

Ogrody Nauk i Sztuk NR 2020 (10) 
We właściwym badaniu wzięły udział 64 matki dzieci przedszkolnych, w wieku od 21 do 47 lat $(M=33,9 ; S D=5,23)$, posiadających od 1 do 4 dzieci $(M=1,63 ; S D=$ $0,678)$, w wieku od 5 miesięcy do 20 lat $(M=5,15 ; S D=3,24)$.

\section{Narzędzia}

Komunikat perswazyjny w postaci pytania „Czy jesteś mamą?” albo „Czy jesteś dobrą mamą?" został zaprezentowany jako tytuł ulotek reklamujących darmowe warsztaty dla matek o tematyce rozwoju dziecka. Szata graficzna ulotek została zaprojektowana w taki sposób, żeby kolory nie kojarzyły się jednoznacznie z żadną płcią. Spośród dwóch projektów ulotek wybranych przez badaczki, sędziowie kompetentni wybrali jeden podczas badania. Ten projekt został użyty w eksperymencie.

Podczas badania sędziów kompetentnych użyto kwestionariusza do oceny ulotek dla sędziów kompetentnych, składającego się z trzech pytań, dotyczących prezentowanej ulotki: $\mathrm{w}$ jakim stopniu ulotka jest atrakcyjna graficznie - oceny na skali od 1 (nieatrakcyjna) do 5 (atrakcyjna) - w jakim stopniu tytuł ulotki rzuca się w oczy - oceny na skali od 1 (nie rzuca się) do 5 (rzuca się) - oraz w jakim stopniu ulotka jest przejrzysta - oceny na skali od 1 (nieprzejrzysta) do 5 (przejrzysta).

Podczas badania użyto kwestionariusza oceny ulotek dla osób badanych, składającego się z trzech pytań: $w$ jakim stopniu ulotka jest atrakcyjna graficznie, na skali od 1 (nieatrakcyjna) do 5 (atrakcyjna); w jakim stopniu treść tytułu zachęca do wzięcia udziału w warsztatach, na skali od 1 (nie zachęca) do 5 (zachęca); oraz w jakim stopniu ulotka jest przejrzysta, również na skali od 1 (nieprzejrzysta) do 5 (przejrzysta). Skuteczność komunikatu perswazyjnego była mierzona jedynie przez pytanie drugie, dotyczące stopnia, w jakim ulotka skłania do wzięcia udziału w warsztatach; pozostałe dwa pytania były pytaniami buforowymi.

\section{ZMIENNE I OPERACJONALIZACJA}

Zmienne główne przyjęte w badaniu zostały przedstawione w tabeli 1 .

Tabela 1. Zmienne główne przyjęte w badaniu

\begin{tabular}{llll}
\hline Rodzaj zmiennej & Nazwa zmiennej & Operacjonalizacja & Skala \\
\hline $\mathrm{X}$ & $\begin{array}{l}\text { Rodzaj } \\
\text { komunikatu } \\
\text { perswazyjnego }\end{array}$ & $\begin{array}{l}\text { Prezentacja ulotki o tytule „Czy } \\
\text { jesteś mamą?" albo „Czy jesteś } \\
\text { dobrą mamą?” }\end{array}$ & Nominalna \\
\hline Y & $\begin{array}{l}\text { Ocena stopnia, w jakim } \\
\text { tytuł ulotki zachęca do } \\
\text { udziału w warsztatach, na } \\
\text { pięciopunktowej skali }\end{array}$ & Interwałowa \\
\hline Źródło: Opracowanie własne & &
\end{tabular}

W badaniu kontrolowano także szatę graficzną ulotek, wiek matek, liczbę dzieci posiadanych przez matki oraz wiek dzieci posiadanych przez matki. 


\section{BADANIE SĘDZIÓW KOMPETENTNYCH}

Celem badania był wybór materiału bodźcowego do eksperymentu - konkretnie jednej z dwóch wersji graficznych ulotki, rzekomo reklamującej warsztaty dla mam.

Badanie zostało przeprowadzone w dniach od 26.11.2018 do 6.12.2018. wśród klientek galerii handlowej Wroclavia oraz pracowniczek firmy Nokia. Badanie odbyło się w następujący sposób: $\mathrm{w}$ galerii handlowej Wroclavia pracowały symultanicznie trzy badaczki, które podchodziły do losowo napotkanych kobiet. Jedna z badaczek przedstawiała się jako studentka Uniwersytetu Wrocławskiego, a następnie pytała, czy kobieta jest matką dziecka w wieku przedszkolnym i czy zgodzi się wziać udział w krótkim badaniu ankietowym. Matkom, które wyraziły zgodę, druga badaczka prezentowała jedną z wersji graficznych ulotki, po czym badana wypełniała ankietę oceniając: atrakcyjność graficzną ulotki, na skali od 1 (nieatrakcyjna) do 5 (atrakcyjna); to, czy tytuł ulotki rzuca się w oczy, na skali od 1 (nie rzuca się) do 5 (rzuca się); a także przejrzystość ulotki, również na skali od 1 (nieprzejrzysta) do 5 (przejrzysta). Następnie prezentowana była druga wersja graficzna ulotki i zbierane były odpowiedzi na takie same trzy pytania, a po ich udzieleniu osoba badana proszona była o dokonanie wyboru, którą z dwóch wersji graficznych ulotki wybrałaby jako materiał reklamowy warsztatów. Kolejność prezentowania ulotek była naprzemienna, by uniknąć efektu zakotwiczenia, ponadto badanie odbywało się zawsze indywidualnie, by matki nie sugerowały się nawzajem swoimi odpowiedziami. Po wzięciu udziału w badaniu, badaczki zbierały informacje metryczkowe dotyczące wieku matki, liczby posiadanych dzieci oraz ich wieku, po czym dziękowały za wypełnienie ankiety.

Badanie w firmie Nokia przebiegało w analogiczny sposób; pracowała tam jednak tylko jedna badaczka.

Na podstawie wyników badania pilotażowego, zwłaszcza analizy częstości preferencji matek, do użycia w eksperymencie został wybrany jeden projekt ulotki.

\section{EKSPERYMENT}

Badanie zostało przeprowadzone w modelu eksperymentalnym, w schemacie jedno-zmiennowym.

Badanie odbyło się w dwóch, losowo wybranych przedszkolach we Wrocławiu: „Mały Kolejarz” oraz „Promyk”, w godzinach popołudniowych w dniach 12.12.2018 i 14.12.2018.

Badanie przebiegało $\mathrm{w}$ następujący sposób: w każdym z dwóch wybranych przedszkoli dwie autorki badania pracowały symultanicznie, lecz niezależnie od siebie. Badaczka podchodziła do matki przychodzącej do przedszkola odebrać dziecko i pytała, czy może zająć chwilę. Matkom, które wyraziły zgodę, przedstawiała się jako studentka Uniwersytetu Wrocławskiego, która zbiera opinie na temat materiałów reklamowych dotyczących warsztatów dla mam, które są planowane przez Uniwersytet i podkreślała, że nie jest autorką ulotki, dlatego prosi o szczere odpowiedzi, gdyż nie sprawią jej one przykrości. Następnie prezentowała wyłącznie jedną ulotkę zatytułowaną „Czy jesteś dobrą mamą?" albo „Czy jesteś mamą?" i prosiła o wypełnienie krótkiej ankiety. Matki oceniały atrakcyjność graficzną ulotki, na skali od 1 (nieatrakcyjna) do 5 (atrakcyjna); to, czy treść tytułu zachęca do wzięcia udziału w warsztatach,

Ogrody Nauk i Sztuk nR 2020 (10) 
na skali od 1 (nie zachęca) do 5 (zachęca); a także, czy ulotka jest przejrzysta, również na skali od 1 (nieprzejrzysta) do 5 (przejrzysta). Skuteczność komunikatu perswazyjnego była mierzona jedynie przez pytanie drugie, dotyczące stopnia, w jakim ulotka skłania do wzięcia udziału w warsztatach; pozostałe dwa pytania były pytaniami buforowymi. Kolejnym etapem badania było zadanie przez eksperymentatorkę pytań jakościowych, które bezpośrednio odnosiły się do odpowiedzi udzielonych przez matkę i dotyczyły proponowanych zmian, które można by nanieść na ulotkę w celu zwiększenia atrakcyjności graficznej, przejrzystości oraz zwiększenia stopnia, w jakim zachęca do wzięcia udziału w warsztatach. Na koniec badaczka zbierała informacje metryczkowe, dotyczące wieku kobiety, liczby posiadanych dzieci oraz ich wieku, po czym dziękowała za pomoc.

\section{WYNIKI}

W celu sprawdzenia, czy skierowany do matek komunikat perswazyjny, odwołujący się do bycia dobra matka, jest skuteczniejszy niż komunikat, który nie odwołuje się do bycia dobrą matka, przeprowadzono analizę testem U Manna-Whitney'a, ponieważ dane nie spełniły warunków normalności rozkładu $(p=0,035)$ i homogeniczności wariancji $(p=0,079)$. Średnia ocena stopnia, $\mathrm{w}$ jakim tytuł ulotki zachęca do wzięcia udziału warsztatach, okazała się wyższa $(M=3,66$; $S D=0,865)$ w grupie, której eksponowany był komunikat odwołujący się do bycia dobrą matką, niż w grupie, której eksponowany był komunikat nieodwołujący się do bycia dobrą matką $(M=3,22 ; S D=$ 1,18). Wyniki analizy testem U Manna-Whitney'a wykazały jednak, że różnice między grupami nie są istotne statystycznie $U=416,00 ; p=0,179$. Przedstawiono je w tabeli 2 .

Tabela 2.Wyniki testu U Manna-Whitney'a

\begin{tabular}{|c|c|c|c|c|c|}
\hline & & statystyka & $\mathrm{p}$ & $\begin{array}{l}\text { różnica } \\
\text { średnich }\end{array}$ & D Cohena \\
\hline $\begin{array}{l}\text { W jakim stopniu treść tytułu } \\
\text { zachęca do wzięcia udziału } \\
\text { w warsztatach? }\end{array}$ & $\begin{array}{l}\text { U Manna- } \\
\text { Whitney'a }\end{array}$ & 416 & 0.179 & $7.88 \mathrm{e}-5$ & 0.422 \\
\hline
\end{tabular}

Źródło: Opracowanie własne

Przeprowadzono również jakościową analizę wypowiedzi matek. Wypowiedzi dotyczyły prezentowanych w badaniu ulotek. Ze wszystkich odpowiedzi $(N=76)$ $66 \%$ odnosiło się do treści tytułu ulotki (w odróżnieniu od pozostałych 34\%). Opinie odnoszące się do tytułu ulotki - a zatem do eksponowanego komunikatu perswazyjnego - poddano dalszej analizie.

Każdą z opinii odnoszących się bezpośrednio do tytułu zaklasyfikowano do jednej z ośmiu kategorii: opinia pozytywna (na przykład: „Tytuł budzi pozytywne skojarzenia” [dobra mama]), opinia negatywna („Treść tytułu jak od świadków Jehowy” [dobra mama], „Tytuł jest tragiczny" [dobra mama], „Taki tytuł to porażka marketingowa” [dobra mama]), opinia neutralna („Tytuł nie przeszkadza“ [dobra mama]), niedobór informacji („Tytuł jest mało precyzyjny” [mama]), odpowiedź na pytanie zawarte w tytule („Nie ma czegoś takiego jak dobra mama” [dobra mama], „Nie 
wiem, czy jestem dobrą mamą" [dobra mama]), proponowane poprawki („,Powinni być uwzględnieni ojcowie” [mama]), nieskategoryzowane („Pytanie tytułowe jest tendencyjne” [mama], „Tytuł przewrotny" [dobra mama]), nieokreślone („Tytuł nic nie mówi" [mama]). Przeprowadzono analizę częstości, która wykazała, że najwięcej opinii należało do kategorii „opinia pozytywna" $(26 \%)$, a następnie kolejno „opinia negatywna” (24\%), „,niedobór informacji” (10\%), „odpowiedź na pytanie zawarte w treści

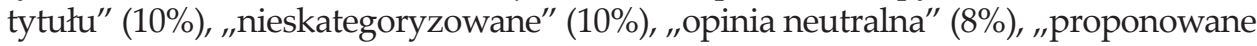
poprawki" (8\%), „nieokreślone" (4\%).

Z punktu widzenia weryfikacji hipotezy, największe znaczenie miał rozkład wyników w kategoriach ",opinie pozytywne", ,"opinie neutralne" oraz „opinie negatywne". W kategoriach tych proporcja wypowiedzi dotyczących ulotek, zawierających komunikat odwołujący się do bycia dobrą mamą („Czy jesteś dobrą mamą?”) oraz nieodwołujący się do bycia dobrą mamą („,Czy jesteś mamą?”), przedstawiała się następująco: $77 \%$ pozytywnych opinii na temat tytułu ulotki zostało wyrażonych przez badane, które oceniały tytuł „Czy jesteś dobrą mamą?”, a 23\% przez badane, które oceniały tytuł „Czy jesteś mamą?”. Dla opinii neutralnych było to odpowiednio 75\% i $25 \%$, a dla opinii negatywnych $50 \%$ i $50 \%$.

W celu sprawdzenia, czy między poszczególnymi rodzajami opinii na temat tytułu oraz rodzajem prezentowanej ulotki występuje zależność statystyczna, przeprowadzono analizę testem chi-kwadrat. Wyniki testu wykazały, że zmienne są niezależne $\operatorname{chi}^{2}(2, N=29)=2,19 ; p=0,335$.

\section{DysKusJa}

Celem badań była empiryczna weryfikacja hipotezy, że skierowany do matek komunikat perswazyjny, który wywołuje presję bycia dobrą matką, jest bardziej skuteczny niż taki, który nie wywołuje presji.

Wyniki nie potwierdzają przyjętej hipotezy. Komunikat perswazyjny, odwołujący się do bycia dobrą matką nie był bardziej skuteczny, niż komunikat nieodwołujący się do bycia dobrą matką. Można przypuszczać, że brak istotnych różnic $\mathrm{w}$ ocenie stopnia, w jakim każdy z komunikatów zachęcał do wzięcia udziału w warsztatach, wynika z dwóch przyczyn.

Jednym z możliwych wyjaśnień jest odwołanie się do teorii dwutorowości perswazji. Model szans rozpracowania przekazu (Petty, Cacioppo, 1990) zakłada, że na postawę wpływa tor perswazji. W przypadku centralnego toru perswazji przetwarzanie jest staranne i przemyślane, natomiast peryferyjny tor perswazji opiera się nie tyle na merytorycznej wartości otrzymanej informacji, ile na powierzchownym zidentyfikowaniu jakiegoś sygnału sugerującego pozytywny lub negatywny stosunek do stanowiska oferowanego w przekazie. Ponadto wiadomo, że obecność pochłaniających uwagę dystraktorów (a przedszkolne szatnie i korytarze są miejscami pełnymi dystraktorów) może uniemożliwić uważne przetwarzanie informacji, stąd opinie badanych matek mogły wynikać wyłącznie z peryferyjnego przetworzenia tytułu ulotki i ocenienia go np. na podstawie wzbudzonej sympatii bądź antypatii przez badaczki.

Warto rozważyć także wpływ emocji na skuteczność komunikatu perswazyjnego. Z badań wynika, że treść wywołująca pozytywne emocje podnosi skuteczność, na- 
tomiast emocje negatywne (a w szczególności strach, któremu poświęcono najwięcej badań) wywołują niejednoznaczny efekt - raz zwiększaja, a innym razem zmniejszają skuteczność perswazji (Leventhal, 1970). Odniesienie się do bycia "dobrą mamą" miało w zamierzeniu wywołać $\mathrm{w}$ badanych matkach negatywne emocje - poczucie winy, wstydu lub być może nawet strach przed niespełnianiem standardów wewnętrznych czy społecznych. Skuteczność przekazu pod wpływem strachu zaś zależy od tego czy odbiorca wierzy, że poradzi sobie z zagrożeniem a do tego niezbędne jest zawarcie w komunikacie wskazówek, jak sobie z nim poradzić. Gdy ich nie ma, nie nasila się uleganie perswazji. Trudno ocenić czy informacja o warsztatach na odwrocie ulotki mogła służyć redukcji strachu. Jedną z możliwych metod weryfikacji tego wyjaśnienia mógłby być pomiar odczuwanych przez matek emocji wywołanych przez komunikat, np. poszerzenie kwestionariusza o pytania ich dotyczące.

Chociaż wyniki uzyskane w eksperymencie nie potwierdziły przyjętej hipotezy, warto kontynuować badania w tym zakresie. W przyszłości można zastosować inny materiał bodźcowy niż ulotki, silniej eksponujący tytuł i jednocześnie niezawierający tak wielu informacji rozpraszających uwagę, a także skierować badanie do nieco innej grupy odbiorów, na przykład kobiet w ciąży. Interesujące mogłyby okazać się również wyniki badania, mierzącego rzeczywiste zachowania, a nie jedynie słowne deklaracje.

\section{Bibliografia}

[1] Carlsmith, J. M. \& Gross, A. E. (1969). Some effects of guilt on compliance. Journal of Personality and Social Psychology, 11(3), 232-239.

[2] Douglas, S. J.\& Michaels, M.W. (2004). The Mommy Myth: The Idealization of Motherhood and How It Has Undermined Women. New York: Free Press.

[3] Hays, S. (1996). The Cultural Contradictions of Motherhood. New Haven: Yale University Press.

[4] Hibbert, S., Smith, A., Davies, A.\& Ireland, F. (2007). Guilt appeals: Persuasion knowledge and charitable giving. Psychology \& Marketing, 24 (8), 723-742.

[5] Howorth, C. (2017). „Motherhood Is Hard to Get Wrong. So Why Do So Many Moms Feel So Bad About Themselves?". Time, vol 190, no 18. Pobrano, 26 kwiecień 2020, z: https://time.com/magazine/us/4989032/october-30th2017-vol-190-no-18-u-s/

[6] Johnston, D.D.\& Swanson, D.H. (2006). Constructing the "Good Mother": The Experience of Mothering Ideologies by Work Status. Sex Roles, 54, 509-519.

[7] Leventhal, H. (1970). Findings and Theory in the Study of Fear Communications. Advances in Experimental Social Psychology, 5, 119-186.

[8] Orenstein, P. (2001). Flux: Women on Sex, Work, Love, Kids and Life in a Half-Changed World. New York: Anchor Books Press.

[9] Petty, R.E.\& Cacioppo, J.T. (1990). Involvement and persuasion: Tradition versus integration. Psychological Bulle$\operatorname{tin}, 107(3), 367-374$

[10] Sample, I. (2017). One Facebook 'like' is all it takes to target adverts, academics find. The Guardian. Pobrano, 4 czerwiec 2020, z: https://www.theguardian.com/science/2017/ nov/13/facebook-likes-targeted-advertising-psychological-persuasion-academics-research

[11] Sutherland, J.A. (2006). "What Can I Do Different? What Could be Better? What Could You Do More?: Guilt, Shame and Mothering Dissertation" (Niepublikowana rozprawa doktorska), University of Akron, $\mathrm{OH}$.

[12] Sutherland, J.A. (2010). Mothering, Guilt and Shame. Sociology Compass, 4 (5), 310-321.

[13] Warner, J. (2005). Perfect Madness: Motherhood in the Age of Anxiety. New York: Riverhead.

[14] Winnicott, D. W. (1965/2018). The maturational processes and the facilitating environment. New York: Routledge. 